\title{
Violence, Criminal Subjection and Political Merchandise in Brazil: An Overview from Rio
}

\author{
Michel Misse*
}

Department of Sociology, Universidade Federal do Rio de Janeiro, Brazil

\begin{abstract}
The author examines the main dimensions of urban violence in the case of Rio de Janeiro, which includes criminal prosecution of violent collective actors and the participation of policemen in the offer of "political merchandise" to the same actors that the police repress.
\end{abstract}

Keywords: Criminality, urban violence, drug trafficking, political merchandise, Rio de Janeiro.

In the 1990s, Brazil began to experience high and growing homicide rates, a process which had gained public visibility twenty years earlier in cities such as Rio de Janeiro and São Paulo. A long and continuous process of social accumulation of violence extended from Rio and São Paulo to other important urban centers and from them to large and medium size cities, in a period that began approximately in the mid 1970s and continues until today. More than one million people, mainly young men, have been assassinated in Brazil in the past thirty years. ${ }^{1}$ The homicide rate, as is known, is an important indicator of the level of criminality in general, and violent crime in particular. In the 1990s, the average rate of homicides in Brazil was 25 per 100 thousand people, while in Rio de Janeiro state in the same period it was 50 per 100 thousand and in São Paulo 34 per 100 thousand. In the following decade, for the first time, the Brazilian homicide reached an average of 27 per 100 thousand people. This increase, however, contrasted with what began to take place in the two largest metropolitan regions of the country (Graph 1).

A reverse process began to occur in the middle of the first decade of the twenty-first century, first in São Paulo and then in Rio de Janeiro. By 2015, the homicide rate in São Paulo had already dropped to 12 per 100 thousand, in a linear and sharp fall since 2002. In Rio de Janeiro the decline was slower, but has accelerated in recent years, with the rate falling to 30 per 100 thousand in 2015. The homicide rates in other large cities, mainly in the country's Northeast, took an

*Address correspondence to this author at the Department of Sociology, Universidade Federal do Rio de Janeiro, Largo de São Francisco, 1/109, Rio de Janeiro, RJ, CEP 20051-070, Brazil; Tel: +55 21 993156527;

E-mail: michelmisse@gmail.com

${ }^{1}$ Officially, according to Ministry of Health data, total assassinations in the entire country from 1996 to 2015 , were 996,694 persons. Some $30 \%$ of that total was in the Rio de Janeiro and São Paulo metropolitan regions. inverse direction, causing the Brazilian rate to rise from 25 to 29 per thousand, even with the drop in the rates in São Paulo and Rio de Janeiro.

A comparative analysis of this process and of its meaning in terms of patterns of criminality in the different regions of the country is the general objective of this article. A closer analysis of what took place in São Paulo and Rio de Janeiro will show that what may have taken place should not be interpreted as if criminality in general had only decreased in some places and increased in others. The shifts between different patterns of crime are known and the migration of violent crime between cities and regions also appears to follow some common trends. The intervention of the state in the current status of criminality is an important explanatory variable, although it is not always sufficient or based on a homogeneous meaning. Criminal organizations of different types should also be considered, as well as the changes in the structure of income and employment in the period. In this paper, I will limit myself to presenting some of the dimensions that I consider the most important for beginning a systematic approach to our general objective.

\section{VARIATIONS IN CRIME RATES: 1990-2015}

There are no regular official statistics on crime in general and violent crime in particular for all Brazilian cities. Since the beginning of the century, there has been a federal government initiative to establish uniform criteria and centralize the processing and reporting of a variety of crimes in all Brazilian states, but the federal system and the fact that the police are organized by state (with the exception of the federal police, which do not operate in routine policing in the cities) impedes extending the initiative, and allow producing reliable official statistics. There has been an improvement in the quality of production of criminal 


\section{Graph 1:}

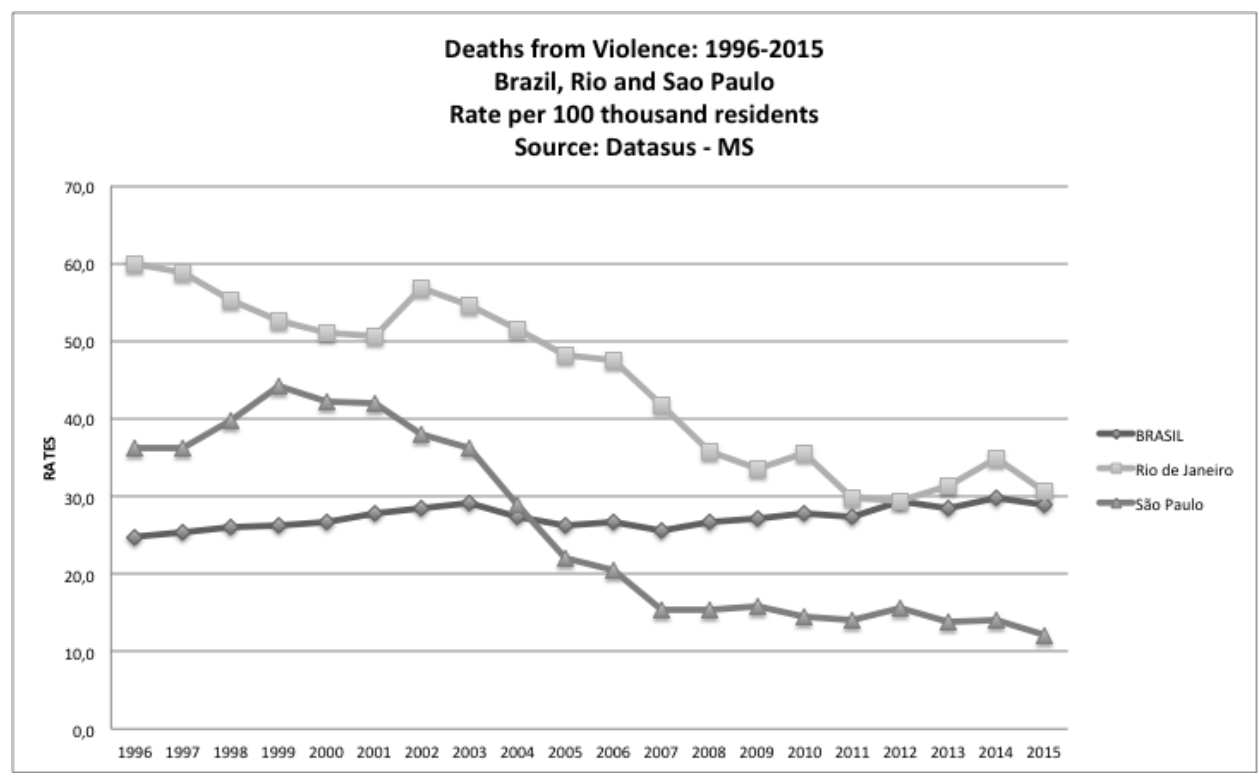

\section{Graph 2:}

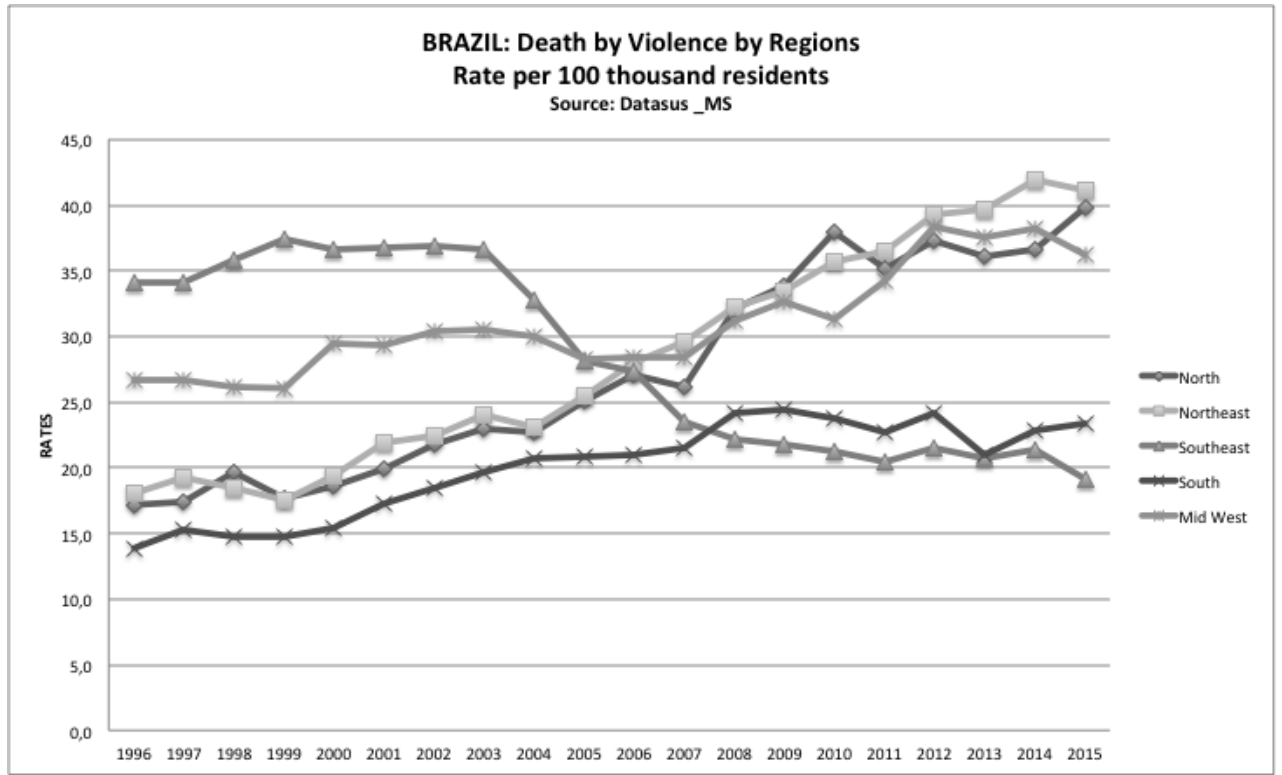

data in some Brazilian states, but not in all, which prevents a comparative analysis. Fortunately, in the cases of Rio de Janeiro and São Paulo, the criminal statistics are of good quality and allow sharper analyses. In other states and large capital cities, in recent years there has been greater concern with the quality of the statistics. Thus, in some cases, what may appear to be an increase in criminality, in reality represents a improvement in the quality of production of data, which comes to encompass areas of the city, the state or of the region which previously did not enter into official statistics.
Meanwhile, there is a national system of health statistics that produces quite reasonable data about mortality rates by disease and from external causes. The main studies about death by homicide in Brazil are based on this source, from the Ministry of Health, which covers all the Brazilian municipalities in a historic series beginning in 1979. It indicates some important variations that took place in the past thirty years in the regions of the country (Graph 2 ).

As we mentioned above, the data indicate, for the period considered, a shift in the increasing homicide rates from the Southeastern region of the country 
[which includes Rio de Janeiro and São Paulo states] towards the North-Northeast and South-Midwest. Recent studies have indicated that this dissemination of lethal violence is partially explained by three factors: social inequality, the low investment of the state in public safety and the existence of criminal organizations. ${ }^{2}$ Nevertheless, in the period considered, the Northeast, like the South, had the best indicators in the country in the decrease in social inequality and increase in average income, and also received strong investments in public safety and are not bases for criminal organizations like those that operate in Rio de Janeiro, São Paulo and other states of the Southeast and Midwest.

In this paper, I do not intend to examine in detail these data or the hypotheses that have been tested by Brazilian scholars. I insist, however, that it is necessary to try to identify common factors that accumulate in time and that a historic approach is indispensable to the understanding of this process that I have called the "social accumulation of violence" (Misse, 1999). The analysis, on the other hand, of the drop in the homicide rate (and of other crimes) in Rio de Janeiro and São Paulo, can allow, contrafactually, the development of hypotheses about this process, as well as a relative understanding of the structural covariates that are usually associated to the explanation of homicides in the specialized literature. ${ }^{3}$

\section{PATTERNS OF VIOLENT CRIMINALITY IN RIO DE JANEIRO AND SÃO PAULO}

The main change in the patterns of urban criminality in Brazil were primarily experienced in Rio de Janeiro and São Paulo, between the late 1950s and the early 1970s. It consisted in a gradual substitution in crimes against life, from the use of knives to the use of firearms and to the relative drop in crimes of passion in relation to conflicts of other types (disputes involving gangs, revenge or extermination groups). In the crimes against property, by the substitution of astute appropriation (various modalities of theft and swindling) to expropriation with the use of violence (armed robbery, break-ins and, as early as the 1970s, kidnappings). Drug trafficking, which existed in an interstitial and irrelevant manner, gained new

\footnotetext{
${ }^{2}$ The main studies about homicide in Brazil, include Jorge (1979), Fajnzylber, P. et al. (1998), Cerqueira, D. and Lobão, W. (2002), Cerqueira, D. (2010), Soares, G. (2008), Cruz, M.V. and Battituci, E. , orgs.(2007), SOUZA, E. (2003), Cano, I., Santos, N. (2001), Andrade, L.T. et al. (2013)

${ }^{3}$ Cf. Soares (2008).
}

dimensions since the mid 1970s, with the entrance of large shipments of marijuana from Paraguay and later with the growing supply of cocaine at increasingly competitive prices in low-income regions or in the urban peripheries of these two large Brazilian cities. ${ }^{4}$

The increase in criminal events was not absorbed by the criminal justice system, which was already operating with difficulties and low integration between the police subsystems and the judiciary subsystem. The low capacity for processing serious crimes and the delays in the system as a whole came to be socially represented as a significant factor in the increased criminality, which for a part of society legitimated the illegal actions of vigilantes against thieves and crime suspects by para-police groups. In Rio de Janeiro the first "death squad" was formed in the late 1950s and in São Paulo, in the 1960s. Thieves and small drug dealers and swindlers began to turn up dead murdered - and marked with a sign indicating the group who executed them. Popular newspapers and radio programs came to specialize in criminal news, publicizing and turning banal macabre images and reports on their pages and broadcasts. The extermination groups spread through the peripheries of the two cities, offering protection to shop owners and small businesses. On the other hand, they also conducted extortion of criminal suspects and charged a portion of the income earned by thieves and kidnappers who fell under their control and threats. These groups were usually formed by police officers, retired police and youths who were co-opted to act as vigilantes. The capacity of the criminal justice system to incriminate them is evidently even lower, given that they reproduce under the protection and indifference of authorities and part of society.

In both cities, during most of the 20th century, part of the police was involved with the reception of stolen goods, mainly gold and jewelry, contraband and "chop shops" (which dismount stolen cars to sell their parts). In the same way, it was always linked to offenders and promoters of prostitution. In Rio de Janeiro, the zone of popular prostitution, known as the "Mangue" [the swamp], survived various urban reform projects and only disappeared in the last decades of the century. In São Paulo, the "Boca do Lixo" district [literally the Garbage Mouth] also survived various periods of

${ }^{4}$ Periphery is used in Brazil to indicate any low income neighborhood with poor infrastructure and public services, and is not defined specifically by geography. 
growth of the city and only recently disappeared. Police and "malandros" 5 offered protection or directly controlled the business of thousands of prostitutes who disputed customers at these locations. Bordellos for the middle and upper class also received police protection, as well as medical clinics specialized in abortion, which operated clandestinely, but which were known to everyone, including the police. This environment of corruption and hypocrisy involved a substantial portion of the police and authorities in the criminal justice system. But the main activity that established dangerous ties between police and authorities with conventional criminality was the "jogo do bicho" or numbers racket.

\section{THE “JOGO DO BICHO” AND THE DISSEMINATION OF POLITICAL MERCHANDISE}

The jogo do bicho [numbers racket] has been found throughout Brazil for at least 70 years. It began in Rio de Janeiro and spread to São Paulo, Minas Gerais, Espirito Santo and later to the rest of the country. It is a very popular lottery to which betters have easy access: there are "points" where people can make bets spread through all the neighborhoods and many streets, with an "apontador" [literally a pointer] who marks the bets in a receipt book, delivers a copy to the better and keep the other for his control. For decades, the numbers were protected by armed thugs who circulated among the points or by police officers who took bribes or were on the payroll of the "bicheiros." The category "bicheiro", which is relatively pejorative, applies to both the person who takes the bets in the streets and to the manager of the points, and the "banker" of the numbers racket, the one who pays the bets and who controls managers and numbers takers in a given territory.

A bet, from the simplest to more sophisticated, involves choosing from 25 "bichos" [animals] numbered in the dozens, hundreds and thousands and offers the gambler a scale of prizes that increases with the number of options chosen. Since the game depends on a relationship of trust between the gambler and numbers taker, since it is clandestine, the payment of

\footnotetext{
${ }^{5}$ Malandro is an attribute used to designate a person or a lifestyle (malandragem). Its origin is Italian (malandrino) and its more universal content is that of the Iberian picaro. In $19^{\text {th }}$ century Rio de Janeiro the term malandro came to represent a social type between a black slave and a free worker who avoided regular work, substituting it for a hedonistic life based on advantages obtained from gambling, at times exploitation of women and even criminal activities such as thefts and smuggling. A malandro would frequently be involved in violent fights, but his main characteristic was cleverness, creativity and a capacity to escape or avoid difficult situations. There is a vast literature about the theme in Brazil. See Antônio Cândido (1970), DaMatta (1979), Misse (1999), Noronha (2003).
}

the winning bets is a certainty shared by all those who participate in the game. It is said that, in the jogo do bicho, more than in any formal institution (where signatures must be notarized, and extensive documentation is required) "what's written is what counts" (on the copy that remains with the gambler). There are no reports of fraud, except, very rarely, "against" a bicheiro, which usually leads to the death of the "apontador" (the person who takes the bets or the employee who protected him).

The territorial nature of the jogo do bicho follows a potentially violent model, since the control of parts of the city "belonging" to a bicheiro can be disputed by other bicheiros, and the protection of the points by gunman intermittently leads to "wars" and death. The organization adopted by the jogo do bicho is similar to a mafia model. Bicheiros and their "family" (sons, brothers-in-law, cousins, and close assistants) divide the city in territories, maintained in a precarious balance or fiercely and violently disputed. In this territory (which can be a neighborhood, various contiguous neighborhoods or even an entire municipality) the bicheiro is known and "respected," has relations with local state and federal politicians and judges, exercises a local authority based on a clientelistic relationship with residents, and supports or even manages football clubs and samba schools, investing part of his capital in contracting players and in the costs of the carnival displays of the samba schools. This model, which began in Rio, is imitated in other states and in some cases the bicheiro attains a projection that the old bicheiros in Rio de Janeiro never had. Recently, the federal police revealed the partners of a rich bicheiro in Goiás and one of the main opposition senators, who is also a prosecutor. He lost his senate mandate, but continues to serve as a state prosecutor.

The traditional jogo do bicho is now in decline, due to competition from similar games offered legally by a federal bank, the Caixa Econômica Federal, which administers the federal lottery. Although it continues to exist in many cities of the country, the bicheiros have diversified their business, either by opening legal companies, or insisting on other types of illegal gambling, such as slot machines, which are found in bars located in the territory of each bicheiro. The need for support led various bicheiros to organize in Rio de Janeiro in the early 1980s. Even so, the death of a bicheiro can lead to violent disputes among his heirs, as took place with the illegal spoils of Castor de 
Andrade in Rio de Janeiro, the "capo de tutti capi" who died in 1999, after a number of imprisonments.

\section{BROAD CRIMINAL ORGANIZATIONS ORGANIZED IN NETWORKS}

Brazil is not a producer of illicit drugs. It does produce the chemical ingredients used to make cocaine paste. Small laboratories have been located and destroyed by the police, but most of the drugs that reach Brazil come ready for consumption. There is a relatively small production of cannabis in the Northeast, always under federal pressure, and which is not enough to supply consumer demand in the country. Most of the illegal drugs, mainly cannabis and cocaine, come to Brazil over the borders with Paraguay, Bolivia and Peru. Brazil is part of international cocaine routes that leaves Bolívia, Peru and Colômbia destined for the United States. The wholesale cocaine trade takes three main routes: one through the Amazon, via Manaus and Belém do Pará, headed for the Caribbean, Nigeria and the United States; another through Goiás, to the Brazilian southeast; and through the triple border region with Paraguay and Argentina, passing through Paraná State; from large farms on the border with Mato Grosso do Sul, Mato Grosso and Rondônia, it heads towards the interior of São Paulo for the ports of Santos and Rio de Janeiro, destined for Africa (Nigeria) and Europe (Spain). The same routes are used to supply the retail drug trade, initially based on the deviation of portions of international trafficking and then in the 1980s, based on specific supply routes. In the 1990s, the route that linked Paraguay to São Paulo and Rio de Janeiro also came to be used for weapons trafficking (AK-47 and AR-15 rifles, grenades, shoulderfired anti-aircraft weapons and machine guns) to supply the dispute for the points of sale between gangs and factions on the hills of Rio de Janeiro and in confrontations with police.

The main criminal organizations involved in retail trafficking in Rio de Janeiro rose within the penitentiary system during the military dictatorship. Since 1968, leftist organizations resisting the dictatorship launched an armed struggle and bank robberies came to be one of the forms for providing resources for the revolution. The military regime sanctioned the National Security law in 1969, which considered as common crimes those committed by the leftist militants. Thus, political militants and common bank robbers were treated under the same law, until it was revoked more than ten years later.

In this period, political prisoners organized themselves in the penitentiaries of Rio de Janeiro to demand rights that they were being denied. The relative victory in their demands, in the first half of the 1970s, created a demonstration effect for the common bank robbers, known among the criminals in general as "the security law gang." They also decided to organize to demand rights and impose their command within the penitentiary system. To do so, and because some of their leaders also considered themselves leftists (although they were not recognized as such by the political prisoners), they came to designate themselves first as the "Falange Vermelha" [Red Falange] and then by the press as the "Comando Vermelho" (CV), the name which stuck. The first report of a prison director referring to this organization formed in the penitentiary system was presented to the government in 1979. It was said that this organization was formed by those who had been condemned for having formed gangs to rob banks. When the political prisoners who were sentenced under the same law gained political amnesty in 1979, an environment of revolt was created among the "Security Law gang," who formed the Comando Vermelho, because they felt they were denied their rights, given that the amnesty did not apply to them. Their motto thus became: "Peace, Justice and Liberty."

In the following years, with the drop in the prices of cocaine in Latin America, when production began in Colombia, the old points of sale of marijuana in the favelas of Rio de Janeiro were taken by members of the Comando Vermelho $(\mathrm{CV})$ and strengthened for the sale of cocaine. Between 1982 and 1985 an organizational model was consolidated interlinking a network of gangs that worked in street sales, based on the protection offered by the $\mathrm{CV}$ within the penitentiary system. $^{6}$ The model developed of a network organization within the penitentiary system has since then been divided in two sectors, an "intramural" and an "extramural." Various "bosses" (who may or may not have been prisoners) controlled the street sales in one or more favelas, ${ }^{7}$ with relative autonomy in relation to the leaders of the $\mathrm{CV}$ and without any organizational tie

\footnotetext{
${ }^{6}$ The main studies about drug trafficking in Rio include: Alba Zaluar (1995, 2004), Michel Misse (1997, 1999, 2006), Marcelo Lopes de Souza (1996), Marcos Alvito (2001), Antonio Rafael (1997, 1998), Luke Dowdney (2003), Rosinaldo Souza (2004), Machado da Silva, org. (2008) and Carolina Grillo (2013).

There are some 700 favelas in the city of Rio de Janeiro, with a total of some 1 million residents. Calculations by the police and researchers agree that there is drug dealing in nearly all the major favelas (Rocinha, Maré, Alemão, Borel, Mangueira, Manguinhos, Jacarezinho, Turano, Acari, Vigário Geral, Providencia), not to mention the housing projects in the low income areas mainly in the Zona Oeste [Western Zone] (Cidade de Deus, Vila Kennedy, Vila Aliança, Cesarão, etc.), which would represent nearly 10 to $15 \%$ of the population of the city in areas under the control of traffickers. Today, more than half of these areas are under the control of the UPPs (discussed below), but even in these areas drug trafficking did not disappear, but took on other forms.
} 
with the wholesale drug dealers. Their capital is the exercise, through violence, of authority in the region, and the contacts with intermediary dealers ("mules") or even wholesalers. In each territory dominated by trafficking, a division of labor is organized and an hierarchy of power that has been maintained for nearly thirty years, although in some areas it has been simplified due to strong police repression in the past decade: a "boss" and his "managers," one for marijuana (known as the "black" manager), another for cocaine (the white manager) and one more for territorial security (the manager of the "soldiers"). Below came the "vapores" (literally the vapors, the direct street sellers, each of whom had an average "load" of 300 units of drugs); the "aviões" [literally the planes] (who work far from the "boca" [literally the mouth, the word used to refer to the point of sale] or even make resales to other places); and the "soldiers", who carry the heavy weapons and are prepared to confront competing invaders (known as the "Germans") or the police.

Since this all took place thirty years ago, there is an entire generation that has been born and socialized in the favelas and housing projects for which the "movement" (the name given to retail drug dealing) ${ }^{8}$ is an integral part of its cultural repertoire. A portion of these youths regularly offer themselves to substitute those who were jailed or killed, to maintain and "strengthen the movement" even when the repression is constant. Similarly, a symbolic reference of a local identity was established - in a social environment that usually lacked other strong collective identities - even for those youths who were not directly involved with drug dealing, which leads them to identify with the local command, at times with the same degree of adhesion that fans have for their football clubs.

The Comando Vermelho sought to oligopolize the market for street sales of drugs throughout Rio de Janeiro state, but in the mid 1980s, another organization arose entitled the "Terceiro Comando" [Third Command] (TC), ${ }^{9}$ which violently disputed territories with the $\mathrm{CV}$. This triggered an arms race among the two commands for control of the most efficient and lethal weapons to guard points of sales and to expand to other favelas. Thus, trafficking in

${ }^{8} \mathrm{Cf}$. Michel Misse, 2008. Today they are known as "firma" [a firm] (Cf. Grillo, 2013).

${ }^{9}$ There is no news of a "second" command. People interviewed in jail told me that the Terceiro Comando was created by the police to weaken the $\mathrm{CV}$ and to benefit from the profits from drug dealing, thus competing with it. military weapons expanded in parallel (including AK-47, AR-15 rifles, machine guns reserved for the armed forces, grenades, anti-air rocket launchers, bazookas, etc.). There were also traffickers who controlled areas considered to be "independent" from the two commands. Over time, dissidents arose and new factions were created in the mid 1990s (Comando Vermelho Jovem (CVJ) [The Young Red Command], Amigos dos Amigos (ADA) [Friends of Friends] and Terceiro Comando Puro (TCP) [The Pure Third Command], raising the dispute with the Comando Vermelho (CV) to unprecedented levels of violence in the city. It was also in mid 1990s that the state governor was forced to accept intervention by federal troops in the city in an operation that temporarily interrupted the violence, but was not capable of breaking up the commands or impeding the return of the disputes in following years.

\section{THE POLICE AS A PROBLEM}

The police increasingly came to adopt an extermination policy, offering bonuses to officers who arrested or killed drug bosses. The successive and intermittent invasions of the favelas and housing complexes by the police produced a rising number of arrests and deaths without the state being able to recover on-going control of these regions from the dealers. One of the perverse effects of this policy was, on one hand, to stigmatize the residents of these areas, which are associated with traffickers and vulnerable to lethal police actions; and on the other hand, to produce a broad sense of revolt and injustice among these residents, who are hostage to both drug violence and police violence. In some areas, many residents come to protect the dealers against a police force that they consider corrupt and violent; in all the regions, however, the fear of traffickers and the disgust for the police drive the local residents into submission and silence. Without support from residents, the police increasingly became one more external and invading force, with which many youths from the area not only do not identify but repudiate as their enemies, referring to them as the "Comando Azul" [Blue Command - in reference to their uniform color], equating them to the traffickers. ${ }^{10}$ At the same time that they capture and kill, the police negotiate protection for the dealers. The deaths of those suspected of being traffickers by the

\footnotetext{
${ }^{10}$ Many of those interviewed allude to the permanent extortion by the police on dealers as the main source of income of the "Comando Azul (the Military Police)"
} 


\section{Graph 3:}

Civilians killed by Police and Police killed in service Rio de Janeiro (Capital): 1996-2015 Source: ISP-RJ

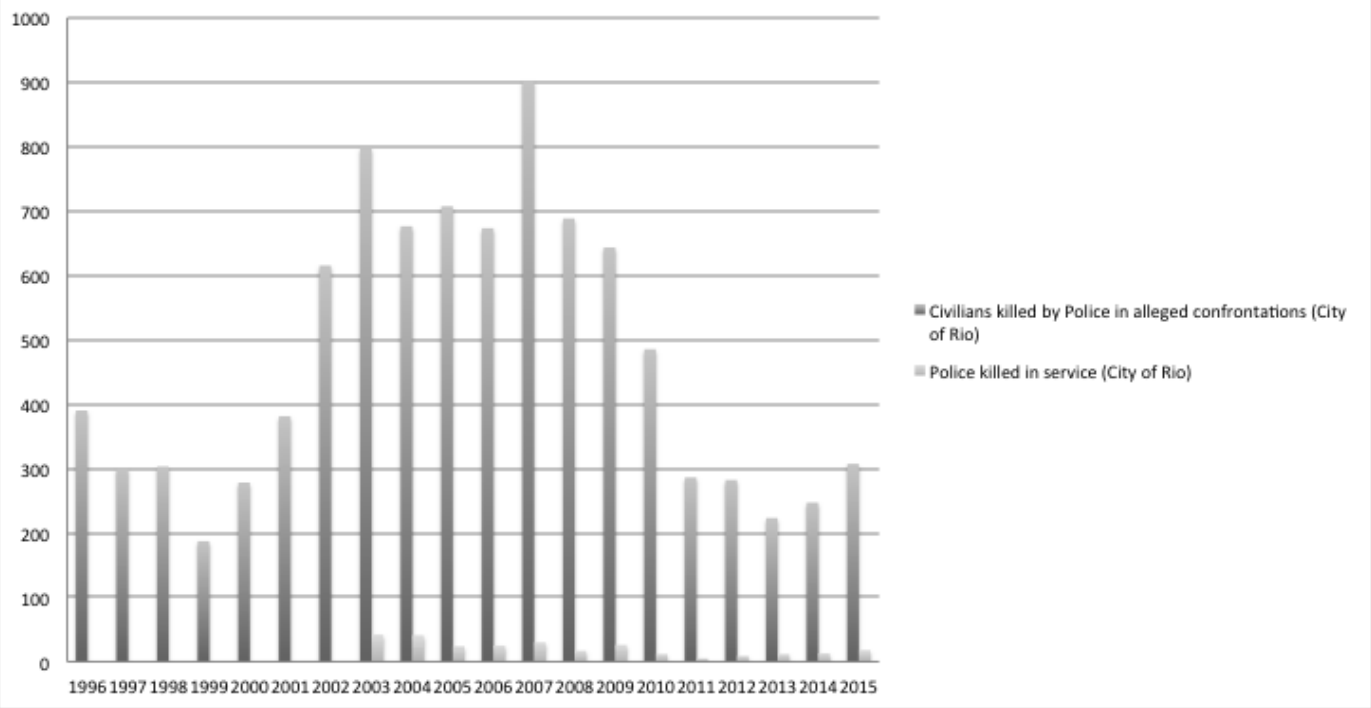

Rio de Janeiro police, in supposed confrontations in which they resisted arrest, reached numbers unprecedented in Brazil or other countries. The relatively low number of police killed in these conflicts indicates an asymmetry of forces (Graph $\mathbf{3}$ ):

In São Paulo, the largest metropolis in South America, until the 1990s there were small criminal organizations in the penitentiaries of the capital city and in the interior of the state, but none that could rival those in Rio de Janeiro. Retail drugs sales were also highly segmented and poorly organized in São Paulo, until the rise of the Primeiro Comando da Capital (PCC) [First Command of the Capital]. ${ }^{11}$ Like what happened in Rio de Janeiro, it was in the São Paulo penitentiary system that this organization arose in 1993, after a mass killing by the police in Carandiru, the state's largest penitentiary. ${ }^{12}$ It remained, however, little known and its growth, exclusively within the

\footnotetext{
${ }^{11}$ There are still few studies about the PCC, a criminal organization that became publicly important only after events in 2003, when it was able to paralyze the city of São Paulo with a series of violent actions. In addition to studies about its origin, written by prosecutors, journalists and family members of inmates - M. Christino (2001), Josmar Jozino (2005), Carlos Amorim (2003), R. Barbatto Jr. (2007), Fatima Souza (2007) - there are now researchers who have begun to reveal the forms of its organization inside and outside the São Paulo penitentiary system Cf. Sérgio Adorno (2007), Guaracy Mingardi (2007), Gabriel Feltran (2007, 2008), Camila Caldeira Dias (2009), Karina Biondi (2006, 2008), Daniel Hirata (2010) and Adalton Marques (2011). About the "world of crime" before the existence of the PCC in São Paulo, see José Ricardo Ramalho (1979).

${ }^{12}$ In 1992, to repress a rebellion at the Carandiru Penitentiary, the state military police invaded various prison wings and shot defenseless rebel prisoners, killing 111 prisoners in what was known as the "Massacre of Carandiru."
}

penitentiary system, benefited from a sense of revolt and injustice among prisoners about prison conditions and the adoption of excessively rigorous disciplinary methods.

In late 1999, the news media reported that an extensive criminal network had formed involving this organization of prisoners of São Paulo and the Comando Vermelho, from Rio. This previewed the "mega-rebellion of 2001," when 29 prisons rebelled in various parts of São Paulo state. In May 2006, the PCC leaders began a new series of rebellions, this time in 73 São Paulo prisons, with repercussions in Paraná and Mato Grosso do Sul, accompanied by a wave of violent actions that paralyzed the country's most important economic center for a number of hours and which lasted a total of four days. At the end, hundreds of deaths were recorded in various parts of the metropolitan region and the interior of São Paulo state. The new criminal organization that rose in the prisons could no longer be ignored.

Like the CV, the PCC is a network of interconnected gangs inside and outside the penitentiary system. Nevertheless, unlike the $C V$, the PCC appears to have a more vertical and organized hierarchical structure. Moreover, it aspires to an organic nature not found in the Commands of Rio, and that involves rituals of "baptism," of the new adhesions, by-laws, fidelity oaths and recognition of a "godfather," to whom the new member accounts to and who is responsible for the 
new member within the organization. ${ }^{13}$ Its members call themselves "brothers" and its motto is the same as the CV, "Peace, Justice and Liberty." Its emblem is the Taoist Yin-Yang symbol. According to researcher Camila Dias, ${ }^{14}$ the form of organization of the PCC, which in the early years (1993-2000) was a pyramid, after 2001 shifted to a "cellular" system, under the influence of its most renowned leader Marcola. ${ }^{15}$ The introduction of an egalitarian principle in the organization of the relations among its members allowed anyone to take decisions "in the name of the PCC," although he would be responsible for the consequences. This principle established a tension with the hierarchical demands of the organization that recognized the limits of its application. ${ }^{16}$ Nevertheless, there are few studies about how the PCC's extramural networks function in the control of drug trafficking. ${ }^{17}$ Nevertheless, there are indications that the networks of gangs tied to the PCC not only deter the monopoly of retail drug sales in São Paulo but to some degree are responsible for the drop in the homicide rate found in the past five years in the state, due to its control over local conflicts using "informal tribunes," known as the "debate". ${ }^{18}$

\section{EXTERMINATION GROUPS AND MILITIAS}

In the 1950s, in Rio de Janeiro, through the initiative of the police chief at the time, the so-called "Special Diligence Group" was formed whose main mission which should be conducted clandestinely - was to execute criminals. This group came to be popularly known as the "Death Squad" and its model disseminated to other Brazilian cities, with the same name. Despite the successive criticisms in the press and from special commissions created to investigate crimes and punish their authors, the Death Squad survived, even after the death of one of its main members, Detective Le Cocq. The men under his command created, as early as the 1960s, the "Scuderie Le Cocq," composed of the self-described "Men of Gold" of the Rio de Janeiro police force. The investigative commissions arrested some of its members, but the group continued to exist

\footnotetext{
${ }^{13}$ Cf. Camila Caldeira Dias, 2009; Karina Biondi, 2009.

${ }^{14}$ Camila Caldeira Dias, op. cit.

${ }^{15}$ This is Marcos William Herbas Camacho, known as "Marcola" and considered until 2006 the uncontested leader of the PCC. He remained in rigorous solitary confinement for six years.

${ }^{16}$ Karina Biondi, 2009.

${ }^{17}$ Among the exceptions, see Gabriel Feltran (2011) and Vera da Silva Telles and Daniel Hirata (2007)

${ }^{18}$ Gabriel Feltran (2011).
}

clandestinely, strengthening itself after the military coup of 1964. Other groups arose, with the same argument of seeking "justice", alleging that the "the police make arrests, but the judiciary frees the bandits." Something one of the members of the Scuderie Le Cocq said in a television interview became famous: "a good bandit is a dead bandit," expressing what a portion of the population thinks about how criminals should be treated. $^{19}$

This semilegal policy of extermination continued throughout the military dictatorship with the rise in the 1970s, in the populated periphery of Rio de Janeiro, of "extermination groups" (this was the name given by the press of the time and that is used until today). They involve small groups of police, prison guards and private security guards who are paid by shop and business owners to "clean-up an area," that is, kill thieves and muggers who work in the region. Another modality is the so-called "polícia mineira", also constituted by groups of police and former police officers, who sell protection to small businesses and shop owners, also offering them services as hit men. The homicide rate in the region, in the 1980s, reached extraordinary levels, mainly because of the action of these groups, who continue to act until today but in a more clandestine manner.

In the 1990s, a new modality of police extortion ("polícia mineira") arose in the favela of Rio das Pedras, in Rio de Janeiro: to prevent traffickers from entering the favela, the protection came to be offered (or extorted) from residents in general and not only from local merchants. Through resident associations, a new model of offering protection was created that combined police gunmen, local community groups and leaders with political ambitions. ${ }^{20}$ The arrangement was quite successful in preventing the entrance of trafficking and exercising social control in the favela, even if for some of the residents the charging of protection fees was seen as a veiled form of extortion.

The model came to be disseminated in other neighborhoods of the Zona Oeste of Rio de Janeiro, giving origin to a mafia type organization known as the "Liga da Justiça" [The Justice League], whose political arm included state and city legislators and the armed portion groups of active and retired military and civil

\footnotetext{
${ }^{19}$ About the theme of "criminal subjection", see Misse (1999; 2006), Teixeira (2011; 2012).

${ }^{20}$ Cf. Marcelo Burgos (2002), Alba Zaluar and Isabel Conceição (2007) and Cano, I. (2008).
} 
police officers, prison guards, firemen and municipal police, and since 2006 have been called by the press "militias." The "Justice League" was strongly repressed after being exposed in news reports, but the militias continue to operate, mainly in Rio's Zona Oeste. The phenomenon of the militias is more varied than the name indicates, because it combines different modalities of territorial control, ${ }^{21}$ although all of them have in common the justification of the "absence of the state" to occupy the place of drug trafficking and offer in its place a variety of illegal services and goods.

There are now some 90 favelas under the control of the so-called "militias." In each of them an armed group controls the distribution of kitchen gas tanks, clandestine Internet and cable TV services and in some areas illegal public transportation by passenger vans. They also prevent drug trafficking from entering the area, although there are cases in which the militias "sell" their territory to the traffickers, when they do not have the expected profits. The Rio de Janeiro state legislature formed an investigative commission to examine the illegalities and violence and the Secretary of Public Safety strongly reprimanded the militias, even arresting and charging the main politicians related to the so-called "Justice League." Nevertheless, and similar to what has happened with drug trafficking, the militias continue to exist in various parts of Rio de Janeiro, even if they have lost their more visible political arm, and if they have become an activity forced into semi-clandestinity.

The model of the militias, like the numbers rackets and drug trafficking, all arose in Rio de Janeiro, and were then adopted in cities in other Brazilian states, nationalizing forms of criminal organizations that have in the recourse to violence one of their main characteristics. The jogo do bicho is found today throughout Brazil, although in decline; there are also drug trafficking networks in all the states and prisoner organizations in at least six states (Rio de Janeiro, São Paulo, Espirito Santo, Mato Grosso do Sul, Bahia and Paraná). Extermination groups and forms of so-called "polícia mineira" [who practice extortion in exchange for protection] are common in North and Northeastern Brazil, in addition to the states mentioned, where there are organizations of prisoners.

\footnotetext{
${ }^{21}$ Cf. Relatório da Comissão Parlamentar de Inquérito da Assembléia Legislativa sobre Milícias (2008); Ignacio Cano (2008) and Fatima Souza (2008).
}

\section{POLITICAL MERCHANDISE}

All three types of criminal organizations addressed in this article are operations that are primarily defined by involving illegal markets. The illegal markets exploited - gambling, drugs, arms and protection have different properties as capital. The illicit drugs and lethal weapons have in common the fact that their value in the market is a function of greater or lesser supply, which depends on the repression that these organizations suffer. The same is not true of gambling and protection. The prices of these two goods depend more on demand, and therefore on the greater or lesser breadth of the clientele. In the case of protection, when there are no spontaneous clients, they can be induced through extortion. In any case, the reproduction of all of these organizations depends on a second type of merchandise that can protect the one who offers protection, protect who controls the territories, protect who negotiates weapons, protect who takes bets in the streets. This involves a good that depends on an effective calculation of power and of the correlation of forces to be able to acquire economic characteristics. For this reason I have called this "political merchandise" (Misse, 1997, 1999, 2007, 2012). They are goods produced in an asymmetrical exchange, nearly always compulsory, although its realization is generally of interest to both parties. Their price depends simultaneously on a political and an economic calculation. It can be produced by the privatization of state attributions by a government employee (this is the case of the variety of exchanges known as "corruption"), or can be produced simply by the possession of sufficient information, strength, power or violence to require an individual or social group to enter into a relationship of exchange (this is the case of the so-called "extortion"). Evidently, a strictly economic interpretation can be made of these exchanges, but this would loose the political dimension and the complexity involved in the social interaction in which they take place.

If we imagine a scale of political goods, the socalled "clientelism" would be its lightest form and extortion through kidnapping and private imprisonment its most severe. The purposes of the exchange do not matter here, whether egoistic or altruistic, whether individual or collective. Different modalities of corruption fill in the range from the lighter form to the more serious form. The gains in this market do not result exclusively from the law of supply and demand, but from a relationship of strength, a power relationship. It is not necessary that this power be 
gained through the attributes of the state, it can be produced independently, as took place before the rise of the modern state. Max Weber refers to this form of gain as specific to "adventure" or "political" capitalism in opposition to modern capitalism, based on a free market and on competition regulated by rational laws. This interpretation tends to confine to the pre-capitalist past the pirates, slave dealers and other merchants whose gains depend on violence. Nevertheless, this form of gain has never disappeared with the advent and hegemony of modern capitalism, it only continues to be produced as a complement to it, even if it is outside the law. It is not possible to understand the reproduction of criminal organizations of all types without making reference to the fact that they produce or are submitted to political merchandise.

In Brazil there are very strong and constant accusations and charges against the police of corruption, especially the police in Rio de Janeiro. There have been countless references over the decades, primarily in relation to prostitution, contraband and jogo do bicho and currently in relation to drugs and arms dealing. In general, three types of references are observed to what is encompassed in the representation of corruption in the Brazilian police: "propina" [bribery] in exchange for not charging a traffic fine or other infractions codified in norms, regulations and state laws; the "arreglo" or negotiated exchange, generally involving criminals and other agents of illicit goods that do not necessarily involve a recourse to violence; and the "arrego", which is an asymmetrical exchange or extortion, generally linked to weapons and drug trafficking (retail or wholesale). ${ }^{22}$ In either of the cases, the reproduction of the criminal organizations of all types becomes particularly dependent on agreements and political exchanges with public agents, among which the police (who control the legal use of arms and strategic information) constitute one of the main types. Unlike the jogo do bicho, which involves the "arreglo" (a negotiated agreement) or even the cooptation of public agents to mount its staff, the police in Rio de Janeiro come to practice the "arrego" (extorsion) on drug dealers, imposing asymmetrical and nearly compulsory political exchanges. One of the best known traffickers in Rio, who is now serving a sentence in the penitentiary of Bangu, paid nearly US $\$ 250,000$ to police officers who had previously captured him, thus negotiating his release. Bribery and "arrego" are

\footnotetext{
${ }^{22}$ About the different forms of political exchange, see Michel Misse (2012). About the difference between arreglo and arrego, see Lênin Pires (2010).
}

commonplace in Rio de Janeiro and in other Brazilian states. Without these political goods, it becomes difficult to understand the relations between violence, criminal organizations and profits in the illegal Brazilian markets.

\section{THE EXPERIENCE OF THE UPPS IN RIO DE JANEIRO AND THEIR LIMITS}

Between the traditional command of street sales and different "agencies" for protection that have developed in Rio de Janeiro in the past forty years, a new situation began to take shape in nearly thirty important urban areas of the city. Baptized as UPPs Unidades de Polícia Pacificadora [loosely Pacification Police Units] they promised to provide something long sought by residents of these areas: the presence of a reliable community police force that served the residents instead of threating and extorting them. For this dream to be realized without greater impediments, the former state governor of Rio de Janeiro, Sérgio Cabral (PMDB) decided to convoke new military police officers, recently hired and trained for this new mission.

Some of the regions with greater urban violence in Rio, such as the Cidade de Deus, in the Zona Oeste, the "morros" or hillside neighborhoods of Babilônia and of Chapéu Mangueira, in Leme, the Ladeira dos Tabajaras and that of Cantagalo/Pavãozinho in Copacabana and Ipanema, the favela Dona Marta, in Botafogo, the traditional morros of São Carlos, in Estácio, Turano and Salgueiro, in Tijuca, the favelas of Santa Tereza, the old Borel da Muda, the Macacos, in Vila Izabel, the traditional favela of Jacarezinho, the complex of Alemão and of Penha, in the suburbs, and the celebrated Mangueira, in Maracanã, are now "territories of the UPPs." All of these territories, under police control, constitute what the former state Secretary of Public Safety José Mariano Beltrame, has called a "security belt," created in preparation for the megaevents, the 2014 World Cup and the 2016 Olympic Games.

What can this mean, if not the finding that "pacification" also has its territories? By raising the national flag and that of Rio de Janeiro on top of the morro of Mangueira, when previously, in the first "conquests" of territories, the flags raised were that of the elite military police force known as BOPE, which had an image of a skull and cross bones crossed by a sword, what difference is being indicated? The territorialization of police power in Rio de Janeiro is one more chapter in this long history, whose contours must be remembered. 
One peculiarity of Rio de Janeiro is that its social history had a constant presence of valentes [tough guys] and donos [bosses] of the morros. There was less of a presence of gangs, as found in other cities (Belo Horizonte is perhaps an example) or of pistoleiros [armed hit men], as in the Northeast, nor is it of a segmented daily criminality, as in São Paulo or Brasilia, or even that found among middle class youth who deal drugs in Rio and other cities, without needing the identity of an urban space and fixed points for drug sales.

The reference to "territory" in Rio was always important, as expressed in fictionalized serial accounts in newspapers and magazines and in news reports from different periods, since those written by Orestes Barbosa in the $1920 \mathrm{~s} .{ }^{23}$ In the same way that the characters of the malandro and of the marginal, who in Rio since the end of the Empire gained a specific urban tone and national visibility by means of samba and cinema, territory, and its combative division among parties or factions, has become a characteristic mark of the former capital of the Republic.

The territories of the maltas de capoeiras, at the end of the Empire, who divided the city into two bands; the territories of the numbers racketeers, whose borders still occupy the police pages of newspapers; the territories where the criminals and marginais take refuge, in the old Zona do Mangue, to the favelas that rose on the hillsides of the city; the drug dealing territories, since the 1970s, where the systematic militarization of the dispute for territories between factions became effective and between the factions and the police; the recent territories of the militias, controlling a different but compulsory supply, of protection and other illicit goods, in various parts of the city; and finally now, the conquest by the police with the tactical support of part of the armed forces, signaling that the territory is no longer at the margin of the state but is fully integrated, with flags and all, to the established order.

It is still too early to know what this respectable investment will lead to, but some hypotheses can be ventured about why it was not made earlier by previous governments. It is necessary to consider some important variables, which even explain the until now quite successful effort to bring to the city (with the

\footnotetext{
${ }^{23}$ Orestes Barbosa, poet, journalist and writer, published chronicles about the criminal subworld in Rio de Janeiro in the twenties and thirties. Cf. Barbosa, O. (1930).
}

ambition of integrating them) the areas previously relegated to the logic of empty lots and broken windows.

The UPPs followed another experience, which was narrower in scope, but very similar at its beginning and known as the Special Areas Police Groupings (GPAEs) created in the government of Anthony Garotinho (19992002). As the name indicates, this was a police strategy for "special areas," territories that would first be "conquered" from the traffickers and later "controlled" by special forces physically located in the area. The program began to work well (in the same sense in which the UPPs also began to do well), but the traffickers were strong enough to continue to operate, even if they avoided violence in the territory, which became tacitly controlled by the police. The program fell apart when the major media in Rio charged that the governor was also "tacitly" accepting that the dealers continue to operate, even if without violence or effective "control" of the territory. Without greater political support, the GPAEs continued to exist as local mini-battalions, but partially lost their initially promised capacity to control the "special area." They did not come to have even one-tenth of the territorial scope of the current UPPs.

Between the GPAEs and the UPPs (and I ask forgiveness for the abundance of initials) rose, mainly in the Zona Oeste, groupings of government agents (off-duty military and civil police, prison agents, firemen and armed civilians), who came to militarily conquer territories previously controlled by trafficking. Organized in networks, these groupings received the names of "militias," as if to seek an informal legitimation for the "collective of citizens" interested in offering protection to the unprotected residents of the different locations, which they turned into their own territories.

The problem was that these "citizens collectives" began to beat, expel and assassinate residents who resisted them or who did not want to contribute to the protection "box." They also came to traffic in the exploitation of different illicit goods - clandestine cable TV, the oligopoly on gas distribution, clandestine and compulsory transportation in vans, and extorted monthly contributions for protection. The volume of homicides, in the Zona Oeste reached such high levels that the militias, already suffering from police pressure, began to hide the bodies. In recent years, the number of disappeared people in the region has been as high as that of homicides. 
How is this possible? How did the traffickers - who were so strong in previous years - cede territories to the militias, if they did not cede them to the police? In first place it is necessary to insist that, for decades, the police preferred to extort the traffickers than expel them from their territories. The word "extortion" is not always suitable to understand what takes place. There was a rearrangement of power that interested both parties, even if the exchange took place under a compulsory and asymmetrical form. On one hand, it is similar to taxation, on the other it is an exchange in which the values are negotiated at each police crackdown.

The repression of trafficking always functioned to establish a matrix of prices, both the price of drugs as well as the fixation of the cost of the political merchandise offered by the police. Different from the time of the jogo do bicho, when the police were often in a subaltern position in negotiations with the numbers racketeers, in the case of drug traffickers, there was a compulsory "arrangement," but a negotiated one, in which the dominant position was that of the police. The less negotiated the exchange, the greater approximation to pure extortion, to so-called "arrego".

The offer of protection has different contents: information about police operations, the release of prisoners, facilitation of the arrival of arms and drugs, casting a blind eye in daily patrols, etc. The growing demand for "arrego" by police and the drop in demand for cocaine in the "movement" in some areas, between 2001 and 2006, led sectors of trafficking to repel the "arrego" and on three occasions, to set fire to buses and shoot at police stations and even municipal and state office buildings.

The weakening of the main faction, the CV, at the time in which the PCC rose and became stronger in São Paulo, allowed agreements to be reached between these networks, but little is known about their extension. One of the indicators that this tie existed is the entrance of "crack" into Rio de Janeiro, a drug that was always avoided by the CV when it was strong. Another indicator of the weakening of the $C V$ was the rise of the ADA (Amigos dos Amigos) [Friends of Friends], a new criminal faction that forced itself into the old and permanent dispute between the $\mathrm{CV}$ and the so-called Third Command.

But there is a dark and unavoidable fact, which marked the ten years that preceded the creation of the UPPs: the mass assassination of suspects by the police, the sadly famous "autos de resistencia" [registers of resistance]. ${ }^{24}$ In this period, more than 10,000 robbery and drug trafficking suspects were killed, most under unknown conditions. Almost none of these homicides went to trial. Combined with the high increase in condemnations for trafficking in the same period, it cannot be underestimated what this meant in terms of the incapacitation of many of the main elements of the networks that constituted the main faction, the $\mathrm{CV}$, which was the most insolent towards police action. It was not by chance that the CV lost the most territory to the UPPs.

Before conquering the territories, it was necessary to seize them, defeat the resistance, approach them militarily with support of the media and public opinion. The challenge to becoming permanent is no longer, as is known, that of "bringing public policies" to the territories, but - as paradoxical as it appears - to deterritorialize them, that is, to integrate them to the city as normalized neighborhoods, to dissolve them as "territories," even "territories of UPPs."

The persistence of a logic of territories indicates once again, the stabilization and establishment in these areas as being at the margins of the state. Favela or "community," the euphemism does not matter, each reifies in the territory social relations of segregation and stigma, of inequality and repression. In this sense, the UPPs will have achieved success when they do not seek permanence, when they do not seek a new (even if well intentioned) territorialization. It is more or less like the federal Family Grant financial assistance program: success depends on the fact that the program come to an end, that is, that its goal is to no longer exist. The great risk is that the territorialization remains and with time, serves once again the reorganization of the main illegal markets: those that offer retail drugs and offer political merchandise.

\section{CONCLUSIONS}

Before the adoption of the new UPPs policy, the homicide rate in Rio de Janeiro began dropping slowly. The acceleration in the drop, since 2011, is certainly a result of the association of two policies: the policy of setting goals for reducing homicides, established two years before the UPPs (Misse, 2013), and the extension of the UPPs to a large number of favelas in the state capital. Together with the drop in homicides, a

\footnotetext{
24“Autos de resistência" [registers of resistance], is the classification that the police give to homicides committed by police officers in service, in supposed legitimate defense.
} 
drop in the other indicators of violent criminality is also observed in the same period, in both Rio and São Paulo. But it is difficult to explain the linear annual drop, which has now stabilized, of violent crimes throughout São Paulo state. The main factors, as recalled by Kahn (2010) and Lima (2009), include, beyond a continued increase in average income and employment in the poorest areas, a strong investment by the state in police forces in the last two decades, especially in homicide investigations. The mass incarceration policy, which tripled the rate of prisoners in the state in the past ten years, must also be remembered. The relative drop in the proportion of youth (the main victims) in the demographic structure of the state in the same period does not appear to have been strong enough to explain the entire drop, but certainly has some influence. The most polemical factor, recalled by anthropologists who study populations of the periphery, would be the social control that the PCC would be exercising together with agents of illicit activities throughout the state, even if they are not affiliated to the organization. If the last explanation is true, the mass incarceration would also be having the effect of strengthening the PCC in the São Paulo prisons, by increasing its ranks.

There is no consensus about the relative importance of these factors, but a recent rupture in the relations of the police bases with youth from the periphery of the city of São Paulo, which caused dozens of deaths among civilians and police, appears to indicate that there had been some type of tacit agreement between the police who act in the periphery and members of the PCC. In any case, the most important intervening variable, that whose omnipresence in the daily life of the illegal markets and of criminality in the large and medium Brazilian cities is constant throughout its social history - the variable whose participation intermittently constructs, at the margins of the state, the criminal subjection and the purchase and sale of political merchandise, and whose inefficiency creates the sense of impunity that strengthens the violent and extralegal solutions - this variable, more than intervening, is decisive in the explanation either of the rise, or the decline in the rates of urban violence in Brazil: it is the police, the police forces, the police officers who take upon themselves the state monopoly of violence, even if in an illegitimate and illegal manner. It is widely recognized that the fear, but also the disdain, for the police in Brazil is stronger than the respect for the institution and indicates a deep historic separation between state and society. The popular demonstrations, which took place in many
Brazilian cities in 2013, protested against precisely this. Responding to this, the federal police and the federal prosecutor's office have decided to extend criminal subjection, over the last years, to the entire political spectrum and to large private and state-owned enterprises. They want to prove that the Brazilian judicial system is egalitarian and that crime is persecuted in all social classes. The notion of "criminal organization" is now widely used and governors, mayors, deputies, large business owners are treated as bandits by the press. To a large extent, their crimes involved political merchandises produced for the support of the political-electoral system. The trivialization of criminal subjection is the newest judicial phenomenon in Brazil.

\section{REFERENCES}

Adorno, S., Salla, F. 2007. -"Criminalidade organizada nas prisões e os ataques do PCC". Revista Estudos Avançados. São Paulo: Instituto de Estudos Avançados da USP, vol. 21, $\mathrm{n}^{\circ}$ 61, 2007: 7-29. https://doi.org/10.1590/S0103-40142007000300002

Alvito, M. 2001. As cores de Acari: uma favela carioca. Río de Janeiro: Ed. Fundação Getúlio Vargas.

Amorim, C. 2003. CV-PCC: a irmandade do crime. Rio de Janeiro, Record, 2003.

Barbato Jr., R. 2007. Direito informal e criminalidade: os códigos do cárcere e do tráfico. Campinas: Editora Milennium.

Beato, C. 2012. Crime e cidades. Belo Horizonte, Editora UFMG.

Barbosa, O. 1930. Bambambã. Rio de Janeiro, Coleção Carioca, Arquivo Público da Cidade do Rio de Janeiro, $1987\left[2^{a}\right.$ Edição].

Biondi, K. 2010. - Junto e Misturado. Uma etnografia do PCC. São Paulo, Editora Terceiro Nome/Fapesp.

Burgos, M. org. 2002. - A Utopia da Comunidade. Rio das Pedras, uma favela carioca. Rio de Janeiro, PUC-Rio e Edições Loyola.

Cândido, A. 1970. "Dialética da Malandragem", Revista do Instituto de Estudos Brasileiros, Universidade de São Paulo, n. 8.

Cano, I. 2008. "Seis por meia dúzia? Um estudo exploratório do fenômeno das chamadas 'milícias' no Rio de Janeiro, in Vários autores, Segurança, Tráfico e Milícias. Rio de Janeiro, Justiça Global e Fundação Heinrich Boll.

Cerqueira, D. 2010. Causas e consequências do crime no Brasil. Tese de Doutorado em Economia, PPGE, Departamento de Economia, PUC-RJ.

Cerqueira, D., Lobão, W. 2002. "Criminalidade: desafios para o próximo governo”. Conjuntura Econômica, v. 56, n. 7.

Christino, M. 2001. Por dentro do crime - corrupção, tráfico, PCC São Paulo, Fiúza.

Cruz, M.V., Batitucci, E., orgs. 2007. Homicídios no Brasil. Rio de Janeiro, Editora FGV.

DaMatta, R. 1979. Carnavais, malandros \& heróis. Rio de Janeiro, Zahar

DaMatta, R., Soarez, E. 1999. Águias, burros e borboletas. Um estudo antropológico do jogo do bicho. Rio de Janeiro, Rocco.

Dias, C.C. 2010. "Ocupando as brechas do direito formal: o PCC como instância alternativa de resolução de conflitos". Dilemas - Estudos de Conflito e Controle Social, Rio de Janeiro, Garamond/Necvu, v. 1, n. 4 
Dias, C.C. 2013. PCC: hegemonia nas prisões e monopólio da violência. São Paulo, Saraiva.

Dowdney, L. 2003. - Children of the drug trade. A case study of children in organized armed violence in Rio de Janeiro. Rio de Janeiro, Sete Letras.

Feltran, G.S. 2007. "Trabalhadores e bandidos: Categorias de nomeação, significados políticos". Revista Temáticas, ano 30, v.15: 11-50.

Feltran, G.S. 2008. "O legítimo em disputa: as fronteiras do 'mundo do crime' nas periferias de São Paulo", Dilemas - Estudos de Conflito e Controle Social, Rio de Janeiro, Garamond/Necvu, v. 1, n. 1.

Feltran, G.S. 2011. Fronteiras de tensão. Política e violência nas periferias de São Paulo. São Paulo, Editora UNESP/CEM/CEBRAP

Garzon, J.C. 2008. - Mafia \& Co. La red criminal en Mexico, Brasil y Colombia. Bogotá, Planeta.

Grillo, C.C. 2008. 'O 'morro' e a 'pista': um estudo comparado de dinâmicas do comércio ilegal de drogas. Dilemas - Estudos de Conflito e Controle Social, Rio de Janeiro, Garamond/Necvu, v. 1, n. 1.

Grillo, C.C. 2013. Coisas na Vida do Crime. Tese de Doutorado em Antropologia, IFCS-UFRJ-PPGSA.

Jorge, M.H.P.M. 1979. Mortalidade por causas violentas no município de São Paulo. Tese de Doutorado. Faculdade de Saúde Pública, Universidade de São Paulo.

Jozino, J. 2005. Cobras e lagartos: a vida íntima e perversa nas prisões brasileiras. Quem manda e quem obedece no partido do crime. Rio de Janeiro: Objetiva.

Mingardi, G. 2007. "O trabalho da Inteligência no controle do Crime Organizado". Revista de Estudos Avançados. São Paulo: Instituto de EstudosAvançados da USP, vol. 21, n 61: 5169.

Misse, M. 1997. "As ligações perigosas: mercado informal ilegal, narcotráfico e violência no Rio de Janeiro". Contemporaneidade e Educação, v. 2, n. 1.

Misse, M. 1999. Malandros, marginais e vagabundos. A acumulação social da violência no Rio de Janeiro. IUPERJ, Tese de Doutorado em Sociologia.

Misse, M. 2006. Crime e Violência no Brasil Contemporâneo. Estudos de sociologia do crime e da violência urbana. Rio de Janeiro, Editora Lumen Juris.

Misse, M. 2007. "Mercados ilegais, redes de proteção e organização local do crime no Rio de Janeiro". Revista de Estudos Avançados. São Paulo: Instituto de Estudos Avançados da USP, vol. 21, n 61:139-157. https://doi.org/10.1590/S0103-40142007000300010

Misse, M. 2009. El delito como parte del mercado ilegal: violência, mercancia política y narcotráfico en Rio de Janeiro, in Ruth Stanley (comp.), Estado, violência y ciudadanía em América Latina. Madrid, Entimema.

Misse, M. 2012. "Estado y mercados ilegales en Latinoamérica: reflexiones a partir del concepto de mercancia política", in Jorge Giraldo Ramirez, ed. Economía Criminal y Poder Político. Medellin, Universidad Eafit.

Misse, D. G. 2013. Políticas sociais em territórios pacificados. Tese de Doutorado em Sociologia e Direito. Niterói, PPGSD/CESA/UFF.
Noronha, Luís .2003. Malandros. Notícias de um submundo distante. Rio de Janeiro, Relume-Dumará.

Pires, L. 2010. Arreglar não é pedir arrego. Uma etnografia de processos de administração institucional de conflitos no âmbito da venda ambulante em Buenos Aires e Rio de Janeiro. Niterói, PPGA-UFF, Tese de Doutorado em Antropologia.

Rafael, A. 1998. Um abraço para todos os amigos. Algumas considerações sobre o tráfico de drogas no Rio de Janeiro. Niterói, EDUFF.

Ramalho, J.R. 1979. Mundo do crime: a ordem pelo avesso. Rio de Janeiro: Edições Graal.

Relatório da Comissão Parlamentar de Inquérito sobre as Milícias. 2008. Rio de Janeiro, Assembleia Legislativa do Estado do Rio de Janeiro.

Silva, L.A.M.,org. 2008. Vida sob cerco. Violência e rotina nas favelas do Rio de Janeiro. Rio de Janeiro, Editora Nova Fronteira/FAPERJ.

Silva, L.A.M., Figueiredo, A. 1978. "A partir de um ponto do jogo do bicho", mimeo.

Soares, G.A.D. 2008. Não matarás. Desenvolvimento, desigualdade e homicídios. Rio de Janeiro, Editora FGV.

Souza, E. R. 2003. "Análise temporal da mortalidade por causas externas no Brasil: décadas de 80 e 90", in Maria Cecília de Souza Minayo, org. Violência sob o olhar da saúde: infrapolítica da contemporaneidade. Rio de Janeiro, Fiocruz.

Souza, M.L. 1996. "Redes e sistemas do tráfico de drogas no Rio de Janeiro: uma tentativa de modelagem". Anuário do Instituto de Geociências, v. 19: 45-60.

Souza, R. 2002. "Narcotráfico y economía ilícita: las redes del crimen organizado en Rio de Janeiro". Revista Mexicana de Sociología, año 66, n. 1: 141-191.

Souza, F. 2007. PCC, a facção. Rio de Janeiro: Record.

Souza, J.C.A. 2008. "Milícias: mudanças na economia política do crime no Rio de Janeiro", in Vários autores, Segurança, Tráfico e Milícias. Rio de Janeiro, Justiça Global e Fundação Heinrich Boll.

Teixeira, C.P. 2011. A construção social do "ex-bandido": um estudo sobre sujeição criminal e pentecostalismo. Rio de Janeiro, Sete Letras.

Teixeira, C.P. 2012. "Frios","pobres" e "indecentes": esboço de interpretação de alguns discursos sobre o criminoso", in Michel Misse e Alexandre Werneck, Conflitos de (grande) interesse. Rio de Janeiro, Garamond.

Telles, V.S., Hirata, D.V. 2007. "Cidade e práticas urbanas: nas fronteiras incertas entre o legal, o informal e o ilícito". São Paulo, Estudos Avançados, USP, v.61: 173-192. https://doi.org/10.1590/S0103-40142007000300012

Vargas, J.D., Misse, M. 2008. "L'évolution de la consommation et du trafic de drogues illicites à Rio de Janeiro". Déviance et Société, v. 32, n. 3: 377-391. https://doi.org/10.3917/ds.323.0377

Zaluar, A. 1995. Condomínio do Diabo. Rio de Janeiro, Editora da UFRJ.

Zaluar, A. 2004. Integração Perversa: pobreza e tráfico de drogas. Rio de Janeiro, Editora da FGV.

Zaluar, A., Conceição, I.S. 2007. "Favelas sob o controle das milícias no Rio de Janeiro". São Paulo em Perspectiva, v. 21, n. 2: 89-101.

\section{DOI: https://doi.org/10.6000/1929-4409.2018.07.09}

(C) 2018 Michel Misse; Licensee Lifescience Global.

This is an open access article licensed under the terms of the Creative Commons Attribution Non-Commercial License (http://creativecommons.org/licenses/by-nc/3.0/) which permits unrestricted, non-commercial use, distribution and reproduction in any medium, provided the work is properly cited. 